\title{
Water service delivery in Pietermaritzburg: A community perspective
}

\author{
JA Smith ${ }^{1}$ and JM Green ${ }^{2 *}$ \\ ${ }^{1}$ C/o Faculty of Science and Agriculture, Community Resources, Pietermaritzburg, Private Bag X01, Scottsville 3209, \\ KwaZulu-Natal, South Africa \\ ${ }^{2}$ Faculty of Science and Agriculture, Community Resources, Pietermaritzburg, Private Bag X01, Scottsville 3209, \\ KwaZulu-Natal, South Africa
}

\begin{abstract}
South African service delivery paradigms are undergoing a period of decentralisation. Local government/local municipalities are the preferred vehicles, selected by national government, to implement national policy, manage and deliver water services to local populations. Municipalities face a significant challenge of reducing apartheid backlogs, raising the level of service delivery and maintaining working systems whilst concurrently undergoing a period of painful re-demarcation and facing financial and capacity crises. Municipalities, forced to recover costs, transfer pressures of payment to households in an environment of massive job losses, decreased employment opportunities, HIV/AIDS and rising household service debts. South Africa's democratic system lends itself to a heightened awareness of community voices and participation, it is this environment, encouraging community involvement, where community perspectives are sought to identify challenges and provide recommendations for the transformation of water service delivery systems. This article highlights the perspective of low-income urban households to the following (community-identified) major water service delivery issues: free basic water, affordability mechanisms and tariff structures, water meters, leakages and water demand management, political platforms for community engagement and municipal administration. Grass-roots perspectives are critical as they provide insight into how implementation strategies are working on the ground. This paper aims to provide a platform for the perspectives of low-income households to water service delivery in Pietermaritzburg, KwaZulu-Natal and provides community-suggested recommendations for the transformation of water service delivery systems.
\end{abstract}

Keywords: municipal water service delivery, free basic water, water tariffs, community

\section{Introduction}

Apartheid operated to produce persistent poverty and extreme inequality by deliberately institutionalising a number of contextspecific causes of poverty (Hunter et al., 2003). Apartheid's policies of separate development ensured that services were delivered along racial lines, with black South Africans receiving inferior and inequitable services, or no services at all (Hunter et al., 2003; Hemson, 2004). The emergence of the new South African democracy in 1994 brought with it expectations of equalisation across racial, gender, socio-economic and geographic boundaries; fair and just delivery of services; access to basic services; and hope that all citizens could own their freedom and dignity. The Reconstruction and Development Programme (RDP) 1994, in an attempt to redress South Africa's skewed water resource and service legacy, recognised the right of all South Africans to access clean water and adequate sanitation for the attainment of household water security (African National Congress (ANC), 1994). Water, critical for the promotion of health and hygiene, was the RDP's primary objective. The right to access water, as stated in the RDP, was translated into national legal obligations, which were reflected in the South African Constitution 1996, which states that, "everyone has the right to have access to sufficient... water" (Republic of South Africa (RSA), 1996). Commensurate with the legislative obligations, as issued in the

\footnotetext{
* To whom all correspondence should be addressed.

용 +2733260 5271; fax: +2733260 5495;

e-mail: green@ukzn.ac.za

Received 9 March 2004; accepted in revised form 11 August 2005.
}

1996 Constitution, the Water Services Act 1997 was adopted as a necessary measure to ensure an implementation framework to "provide for the rights of access to basic water supply and basic sanitation" (RSA, 1997). The "sufficient" volume of water referred to in the Bill of Rights (RSA, 1996) was re-worded as "basic" and defined as the "prescribed minimum standard" of water supply services necessary for the reliable supply of a sufficient quantity and quality of water to households to support life and personal hygiene (RSA, 1997). The minimum standard for basic water supply services, as provided by the Water Services Act 1997 is:

- "the provision of appropriate education in respect of effective water use; and

- a minimum quantity of potable water of $25 \ell$ per person per day or $6 \mathrm{k} \ell$ per household per month. . within $200 \mathrm{~m}$ of a household" (RSA, 1997).

The South African constitution guarantees all people the right to access adequate and affordable potable water to meet basic domestic needs; and "water and sanitation services should be delivered equitably, affordably, effectively, efficiently, sustainably and gender sensitively to satisfy sector goals" (Republic of South Africa [RSA], 1996; Department of Water Affairs and Forestry [DWAF], 2003).

However, the Growth, Employment and Redistribution Strategy (GEAR) introduced in 1996, ushered in a new era of institutionalised neo-liberalism and cost-recovery, and substantially shaped the texture and direction of certain infrastructure policies (Khosa, 2000). The delivery of water services, historically a duty of the state, shifted resolutely to municipalities 
(Hemson, 2004). Municipalities were the vehicle selected by national government to address the dual water service delivery challenge: to reduce the apartheid backlog whilst concurrently raising the level of service delivered (Hemson, 2004). Yet municipalities, undergoing a period of painful re-demarcation (amalgamating racially defined jurisdictions, urban and rural, rich and poor municipalities) coupled with major capacity problems, were simultaneously faced with a reduction in intergovernmental transfers from national to local government as well as being forced to put caps on the levy rates on properties that they (municipalities) could charge their residents, business and industry (RSA, 2000; Atkinson, 2002; McDonald, 2002a). Municipalities, having a limited tax base and few alternative sources of income, and expected to implement "unfunded mandates" transferred the pressures of payment onto their citizens (McDonald and Pape, 2002). Noting that water rights had not been enacted yet, with advances made in the roll out of water infrastructure and the connection of increasing numbers of households to the water reticulation system, it became apparent that the access to infrastructure did not guarantee household water security. At this time, where citizens were forced to pay for their services, the socio-economic environment did not enable this ability to pay: job losses were escalating, employment opportunities were decreasing and apartheid's legacy of institutionalised poverty and inequality was reluctant to release its hold (HSRC, 2002; Hunter et al., 2003). Low-income households now connected to water systems faced an economic constraint to water access: households had to pay for their water services and this proved to be very difficult or near impossible. Low-income households faced an often desperate situation, either to pay for services on meagre incomes, thereby compromising other essential needs, or face the constant uncertainty of disconnection and indignity or illness/death from a reduced or unsafe water supply.

The payment boycotts, prominent in the 1980s and early 1990s, which formed a large part of the black majority's struggle for equity and citizenship, returned as a site of struggle, but this time the reasons were based on the inability of low-income households to pay for their basic services as well as a response, by households, to inferior service infrastructure and poor service delivery progress. In an attempt to stop citizen resistance, remedy the damage to DWAF's image caused by the hundreds of lives lost in the August 2000 cholera epidemic and absorb the pressures of the joint South African Municipal Workers UnionRural Development Services Network campaign for 50 litres per person per day; the African National Congress, as part of their campaign, in the lead up to the December 2000 municipal elections, announced that (the ANC-led local government), "would provide all residents with a free basic amount of water, electricity and other municipal services, so as to help the poor" (ANC, 2000). This theory is disputed; DWAF submits that, the feasibility for the provision of a basic level of water supply free to poor citizens had been investigated from early 2000 . Further to this, Durban Metro (Ethekwini Municipality), had already been supplying groups free of charge and the Durban model was tested on other selected municipalities (Sussens and Vermeulen, 2001). Unsurprisingly, there has been much debate regarding both the timing of the Free Basic Water [FBW] policy and the final volume offered. The deconstruction of this debate is beyond the scope of this paper; suffice to indicate that groups, with diverse ontological emphases, are divided as to the magnanimity of such a policy. Although the authors regret the oversimplification of such differences, it is useful to categorise the different views: the $1^{\text {st }}$ group believes that FBW was influenced more by the desire to reduce accountancy costs, forward cost-recovery and legitimise imposed restriction devices than to realise the human right to water; and the $2^{\text {nd }}$ group believes that the FBW policy is indeed commensurate with the goals of poverty alleviation and gender equity and is making a valuable contribution to decreasing household expenses and promoting water security for lowincome households.

Differences aside, the South African government announced that from 1 July 2001, a basic supply of free water would be extended to all households. The primary target of the policy was poor households for whom free basic services represents a significant poverty alleviation measure and poor households would benefit the most from an affordable basic water supply (DWAF, 2002a). Within this new policy framework, DWAF is undergoing a period of decentralisation. DWAF will remain "a regulator, a policy maker and a supporter" but all other national water responsibilities will be transferred to local government (DWAF, $2002 \mathrm{~b}$ p15). This provides the Department of Provincial and Local Government and municipalities with numerous challenges in that their capacity will have to be substantially increased if they are to take on their new roles efficiently. Decentralisation of water services to local governments comes at a time when service delivery challenges are greatest; municipalities are expected to do more with less and do better with what they have. The initiation of the FBW policy has substantially changed the nature of water service delivery mechanisms; the relationship between citizens and municipalities; and the conscientisation of households regarding rights, water requirements and delivery systems. All of which bring municipalities to the fore as deliverers of the promise of 'a better life for all' (which gains increasing significance ten years into a democratic South Africa) and places citizens in an optimal position to make justified demands that these promises (and their quality) are realised within time frames that are not necessarily commensurate between stakeholders.

This paper aims to provide a platform for the perspectives of low-income households to water service delivery in Pietermaritzburg, KwaZulu-Natal, within the Msunduzi municipal jurisdiction, and provide community-suggested recommendations for its improvement. The following issues are highlighted as necessitating urgent attention: free basic water, affordability, tariffs and cross-subsidisation, meters, leakages and water demand management, political platforms for community engagement and municipal administration.

\section{Methodology}

This paper is based on a Masters dissertation, which sought to reveal whether South Africa's water service delivery policies and strategies were equitable, accessible, affordable, efficient, effective and sustainable for Pietermaritzburg low-income households (Smith, 2003). The study took its entry point from DWAF's sector goals as issued in the Draft Paper on Water Services (DWAF, $2002 \mathrm{~b}$ p 8 ) and subsequently the Strategic Framework for Water Services (DWAF, 2003 p9). The chief objective of the study was to document community experiences of national and local water policy, strategy and implementation processes and to link these experiences to a broader analysis and interpretation of policy and strategy to identify water service delivery contraventions, inconsistencies and inadequacies.

The study was conducted in Pietermaritzburg, KwaZuluNatal, within the Msunduzi municipal jurisdiction, under the uMgungundlovu district municipality (DC22) in the period from October 2002-April 2003. Households in five low-income urban areas were included in the study: Imbali (Units 1 and 2), 
Sobantu, Haniville and Thembalihle. A community action research design using non-probability sampling was employed in the study. Community researchers participated in the research process and contributed to the methodology, synthesis and collation of surveys, data collection, analyses of the results, suggested reforms to policy and strategies, and formulated community strategies to support the reforms. Community researchers conducted surveys with 314 low-income households. Community focus groups, workshops, meetings and community visits provided qualitative substance to the surveys. Community exchange visits, with participating community researchers, facilitated a greater awareness and analysis of the water service delivery situation in the 5 study areas. Informal engagement with local government departments and civil society organisations complemented surveys and community engagement thereby providing a valuable data triangulation mechanism. No ward councillors were included in the study. Theirs was a purposeful exclusion because the study was seen as a threat and viewed with animosity at best and resulted in harassment and violence at worst. Although the study sought to engage all stakeholders, it is important to note that community voices were privileged because it is these voices that are comparatively more marginalised.

\section{Socio-economic and community characteristics}

The majority of households (83.5\%) had a total income of less than R1 200/month; the average total monthly household income for all areas in the study was R932.17. The households were therefore characterised as low-income households (earning less than the minimum South African income of R1 100 as used by Department of Provincial and Local Government [DPLG], 2003). Fifty nine point six per cent $(59.6 \%)$ of households earned the midpoint of the range of R600 to R1 200 (R900) per month and $23.9 \%$ earned the midpoint of the range of R0 to R600 (R300) per month.

The average household size for all households, included in the study was 5.4 persons per household (accessed via survey data). Study data is not commensurate with the Census (2001) statistics, which put average household size at 3.9 persons per household (Statistics South Africa, 2003 and Coetzee \& Newport-Gwilt, 2003). The average provincial (KwaZulu-Natal) household size is 6 persons per household and national average is 5.4 persons per household. The vast disparity between average household size, as per study, and average household size, as per Census, 2001, may be attributed to numerous possibilities:

- In the census data, average household size is not differentiated in racial demographic terms

- Study and census data did not include outbuilding dwellers or cluster household residents

- In Pietermaritzburg, an educational-orientated city, with a high student population, $18 \%$ of households consist of only a single person [which is much higher than the national aver-

Although the authors accept the average household size of 3.9 persons per household, as indicated by Statistics South Africa (2003), we assert that the study figure of 5.4 persons per household is more accurate (refer to Fig. 1). The majority of households (59.7\%), had more than 4 persons per household, and fell into the higher population size range (refer to Table 1). Community researchers were instructed to include just household members living in the main household, and not those living in outbuildings on the property. This was clearly an oversight, by the authors and a limitation for the study. However, post-survey, this question and others were addressed in focus groups (with community researchers and community members in the 5-study 


\begin{tabular}{|c|c|c|c|c|c|c|c|}
\hline \multicolumn{8}{|c|}{$\begin{array}{c}\text { TABLE } 1 \\
\text { Average household size per study area under Msunduzi Municipality }\end{array}$} \\
\hline \multirow[b]{2}{*}{$\begin{array}{c}\text { Number } \\
\text { of } \\
\text { people } \\
\text { per } \\
\text { house- } \\
\text { hold }\end{array}$} & \multicolumn{7}{|c|}{ Study areas } \\
\hline & $\begin{array}{l}\text { Imbali } \\
\text { Unit } 1\end{array}$ & $\begin{array}{l}\text { Imbali } \\
\text { Unit } 2\end{array}$ & Haniville & Sobantu & $\begin{array}{c}\text { Themba- } \\
\text { lihle }\end{array}$ & $\begin{array}{c}\text { Total } \\
\text { number } \\
\text { of house- } \\
\text { holds } \\
\text { per study } \\
\text { area } \\
\end{array}$ & $\begin{array}{l}\text { Per } \\
\text { cent } \\
(\%)\end{array}$ \\
\hline 1 & 1 & 2 & 3 & 0 & 2 & \begin{tabular}{|l|}
8 \\
\end{tabular} & 2.5 \\
\hline 2 & 5 & 1 & 5 & 5 & 8 & 24 & 7.6 \\
\hline 3 & 7 & 5 & 16 & 4 & 9 & 41 & 13.1 \\
\hline 4 & 8 & 8 & 19 & 9 & 10 & 54 & 17.2 \\
\hline 5 & 8 & 10 & 13 & 9 & 12 & 52 & 16.6 \\
\hline 6 & 4 & 3 & 12 & 8 & 8 & 35 & 11.1 \\
\hline 7 & 10 & 6 & 5 & 15 & 5 & 41 & 13.1 \\
\hline 8 & 3 & 3 & 7 & 12 & 1 & 26 & 8.3 \\
\hline 9 & 2 & 0 & 4 & 5 & 2 & 13 & 4.1 \\
\hline 10 & 2 & 0 & 2 & 3 & 2 & 9 & 2.9 \\
\hline 11 & 1 & 0 & 0 & 2 & 1 & 3 & 1.0 \\
\hline 12 & 0 & 0 & 1 & 3 & 0 & 5 & 1.6 \\
\hline 13 & 2 & 0 & 1 & 0 & 1 & 3 & 1.0 \\
\hline Total & 53 & 38 & 88 & 75 & 60 & 314 & 100.0 \\
\hline $\begin{array}{c}\text { Average } \\
\text { house- } \\
\text { hold size }\end{array}$ & 5.6 & 4.9 & 5.1 & 6.5 & 5.0 & $\begin{array}{l}\text { Average } \\
\text { areas }\end{array}$ & $\begin{array}{l}\text { or all } \\
5.4\end{array}$ \\
\hline
\end{tabular}

\section{Free basic water}

The South African government announced that from 1 February 2001, a basic supply of free water would be extended to all households, however the primary target of the free basic water policy was poor households for whom free basic services represent a significant poverty alleviation measure and poor households would benefit the most from an affordable basic water supply (DWAF, 2002c). The extension of free basic water to poor households was recognised by government, as a significant poverty alleviation measure, with positive implications for public health, gender and equity (DWAF, 2002c p7). President Mbeki stated, 'the provision of free basic amounts of water and electricity to our people will alleviate the plight of the poorest among us' (Mbeki, 2001).

The volume of water offered through the free basic water policy is recommended as $6 \mathrm{k} \ell / 6000 \ell$ of potable water per household per month: disaggregated, $6 \mathrm{k} \ell$ per household per month, provides $200 \ell$ per household per day, or $25 \ell$ per person living in an 8-member household per day (Kasrils, 2001). $6 \mathrm{k} \ell$ of free basic water is delivered per household per month, via individual

areas) and the following was broadly agreed: Approximately a quarter to a half of all houses (exact number unknown) had outbuilding dwellers (nuclei family who moved out of main household for space or relationship reasons, extended families and/or paying residents). Unaccounted-for outbuilding dwellers influenced the total household volume of water consumed. There was no differentiated regulation of water use between those members living in the main household and outbuilding dwellers; this was facilitated by the fact that water connections were situated on-site (not in-house). Outbuilding dwellers had the same access to water supply services as any other "normal' main household member. If rent was paid by outbuilding dwellers to the 'landlord' in the main household, it was not clear whether a portion of this rent was paid towards service expenses and it was further found that very few outbuilding dwellers actually paid contributions to services on top of rent payments.

Almost all households (98.4\%), in the study, had on-site taps (not in-house). Water services were delivered through one tap connected above a concrete sink and attached to water-borne sewage, which was housed within a small concrete structure. Water was used at the sink or carried by buckets or other containers to the homestead. Water was used for a variety of household purposes, e.g. cooking, drinking, cleaning, washing clothes, bathing, sanitation, economic purposes and small food gardens. The areas in the study had the following physical resources (however, the degrees of accessibility and effectiveness varied): roads, transport, clinics, schools and spaza shops. All households included in the study resided in formal urban settlements. No informal settlements were included in the study. Dwelling types were generally of limited size with building materials of concrete blocks and corrugated iron roofing materials and housing extensions of concrete blocks, wattle and daub and shack material of corrugated iron, wooden planks, cardboard sheets and plastic. metered connections. This is commensurate with the Water Services Act (1997), which states the minimum standard for basic water supply services as a "minimum quantity of potable water of $25 \ell$ per person per day or $6 \mathrm{k} \ell$ per household per month...within $200 \mathrm{~m}$ of a household" (RSA, 1997: para 475). The addition of 'or' provides a legal loophole with the implication that regardless of how many members one has in ones' household, the amount of free basic water supplied remains $6 \mathrm{k} \ell$ per month and all citizens may not be equally guaranteed their right to $25 \ell$ of water per person per day.

The free basic water policy is driven by the national Department of Water Affairs and Forestry but set and implemented by local governments. The free basic water policy states that 'the provision of the basic amount consumed by poor households per month is free of charge' however the policy allows local governments through their 'water services authorities to decide how they will apply the policy specifically and practically' (DWAF, 2003: 29). This clause is a significant inclusion because it provides leeway for municipalities to decide on the specific mode of delivery and how much water is to be provided (may or may not amount to $6 \mathrm{k} \ell$ per household). Municipalities have three options when deciding how to implement the free basic water policy:

- Provide a free allocation of water just to the poor free of charge (i.e. targeted);

- Provide a free allocation of water to everyone free of charge; or

- Provide a free allocation of water to everyone free of charge but if domestic users consume more than the free allocation than they must pay for the free allocation of water and any additional kilolitres consumed, i.e. the subsidised cost of the full free allocation plus additional kilolitres used over the free allocation (at the standard tariff rate).

The Msunduzi Municipality, adopted the $3^{\text {rd }}$ option and began implementing the policy in Pietermaritzburg, under the Msun- 
duzi Municipal authority, on 1 December 2001 (Free Basic Water: proposed interim policy implementation. Msunduzi Municipality, 2001). The free allocation of water was $6 \mathrm{k} \ell$ per household per month.

\section{Basic water requirements and water volume con- sumed}

The FBW policy, as implemented in the Msunduzi Municipality, allowed for $6 \mathrm{k} \ell$ per household per month, $200 \ell$ per household per day or $25 \ell$ per person per day (per 8-member household). If households consumed more than $6 \mathrm{k} \ell$ per month, than the access to 'free water' was waived and households were expected to pay for their 'free water' (albeit at a subsidised rate) and thereafter the full costs (at the standard tariff rate) for additional $\mathrm{k} \ell \mathrm{s}$ consumed. Before we indicate whether low-income households (the prime targets, identified by DWAF and the ANC, of the free basic water policy), were consuming within the free basic water range, thereby benefiting from the policy, let us first consider whether $6 \mathrm{k} \ell$ is enough to serve as a lifeline tariff. Over the years, the United States Agency for International Development, the World Bank and the World Health Organisation have recommended between $20 \ell$ and $40 \ell / \mathrm{cap} \cdot \mathrm{d}$, all of which exclude water for cooking, bathing and basic cleaning (Gleick, 1998). Contemporary research is indicating that, to meet basic needs and satisfy health, basic water requirements range from $50 \ell$ to $150 \mathrm{\ell} / \mathrm{cap} \cdot \mathrm{d}$ (Gleick, 1996; McDonald, 2002b; COSATU and SAMWU, 2003; Falkenmark, 2001 cited by Asheesh, Ruohonen and Al-Otaibi, 2003; Howard and Bartram, 2003).

The former Minister of Water Affairs and Forestry, in a newspaper debate with the authors, defended the offering of $25 \mathrm{l} / \mathrm{cap} \cdot \mathrm{d}$ when he asserted that, ' 25 litres per person per day is a widely accepted and internationally applied norm' (Kasrils, 2003). Kasrils's assertion is not wholly wrong. National and international recommendations regarding the water volumes required to satisfy minimum domestic water and sanitation needs are diverse and as yet inconclusive. However, $25 \ell /$ cap $\cdot d$ falls at the lower-end of the continuum, with the implications that certain essential water activities will be compromised, which make it difficult for DWAF to achieve its free basic water objectives of alleviating poverty, addressing public health, gender, equity and household affordability constraints. Hazelton (2002:1) confirms this by conceding that "the amount of water, usually between 25 and $50 \ell /$ day per person or between 6 and 8 kilolitres per month per household, as defined by the utility or government regulations, which is considered to be the minimum required by humans for direct consumption, the preparation of food and personal hygiene. It is not considered to be adequate for a full, healthy and productive life."

Households engaged in the following water use activities: bathing, washing clothes, flushing toilet, washing dishes, cooking and food preparation, washing floors, washing hands, face and brushing teeth, water for drinking and water for productive usage. Individual water consumption volumes were accessed from all households included in the study, and ranged from $25 \ell$ to $200 \ell /$ person $d$. However, these figures were not differentiated according to household demographic characteristics nor joint domestic benefit. Community researchers further indicated that household respondents had great difficulty in estimating water usage per individuals. Consumption figures per household, via water bills were not accessible. It was therefore decided that greater accuracy of household water consumption would be accessed via Municipal consumption statistics. However, individual household consumption figures were denied to the authors, therefore average low-income consumption figures, provided by Msunduzi credit control, was the only option in determining average low-income consumption. Subsequently, Msunduzi credit control statistics indicated that low-income households in Msunduzi consumed between 20 and $25 \mathrm{k} \ell$ of water per household per month (Msunduzi Credit Control, 2003). Using the midpoint of $22.5 \mathrm{k} \ell$, households as per Msunduzi credit control statistics, were consuming $750 \ell$ per household per day or $93.75 \ell$ (8-member household) per person per day. Low-income households were consuming far more than $6 \mathrm{k} \ell$ per month. It was evident that $6 \mathrm{k} \ell$ was not sufficient to satisfy the basic water requirements of low-income households. Furthermore, the following household demographics or variables had an impact on water volume consumed: household size/ number of people sharing water connection; number and age of dependants (frequency of water activities increases and opportunities for sharing water reduced); ill household members (specifically people living with HIV/AIDS whose hygiene goals are essential for well-being and sharing water reduced); time spent by members at home (time increased if members unemployed, ill or aged; therefore decreased opportunity for off-property water access); size of cistern and frequency of flush (frequency of flush increases for households with ill members and menstruating women); differentiations of weekday and weekend (respondents indicated that water usage doubled on weekends); cultural and religious practices (e.g. burial rituals and funerals) and water for productive use and multiplier effects. Perhaps low-income communities may be excused for demanding that basic volumes of water, commensurate with the water rights of South African citizens, should be extended to all low-income households to ensure that full, healthy and productive lives be attained?

A high proportion $(81.9 \%)$ of households indicated that the water consumed was sufficient for household activities. However, households' consumption was not restricted by economic or punitive measures for non-payment, as the Msunduzi Municipality had not implemented a broad credit control policy. Households continued to use water, as required, satisfying their dignity, well-being and productivity requirements. Water bills continued to arrive, arrears increased and household debt escalated. However, few households limited their water consumption (only 10 out of 314 households had initiated self-restriction mechanisms). Households, unable to make their monthly payments, maintained that their consumption was legitimate; they were not over consuming but consuming within the water requirements of their households. Households unable to pay for their water and exceeding the FBW utility, continued to reap the benefits of an unrestricted water supply, maintaining that water is essential for life, a basic citizen right and a gift from God. A gift that they cannot live without. Inability to pay therefore, should not, according to these households, restrict their access. It is envisioned that until credit control is institutionalised and monetary value attributed to water, water usage patterns will remain unchanged. When restrictions do become institutionalised, will households be satisfied and able to continue meeting daily household water requirements within the Msunduzi municipal restrictions? Research indications that the water requirements of low-income households are not sufficiently addressed by the FBW policy, point to the inference that households, if forced by credit control policies to remain within the $6 \mathrm{k} \ell$ allocation, will struggle to meet their daily water requirements. This will have major implications for household dignity, health and well being, productivity, the performance of daily water activities, increase the burden of women and lead to conflict, anger, frustration and possibly organised struggle. Households may be forced 


\begin{tabular}{|c|c|}
\hline \multicolumn{2}{|c|}{$\begin{array}{c}\text { TABLE } 2 \\
\text { Average basic service expenditures for } \\
\text { low-income households, included in study }\end{array}$} \\
\hline Water $(22.5 \mathrm{k} \ell$ average $)=$ & $=\mathrm{R} 109.80$ \\
\hline Electricity & R200.00 \\
\hline Waste removal (flat rate) & R 19.53 \\
\hline Sewage (flat rate) $=$ & $=\mathrm{R} 20.75$ \\
\hline $\begin{array}{l}\text { Total (excluding VAT and arrears } \\
\text { repayments) }\end{array}$ & $=\mathbf{R 3 5 0 . 0 8}$ \\
\hline
\end{tabular}

to tamper with restriction devices to secure their basic water requirements or compromise other essential service expenditures in efforts to secure more water. Any policy that turns legitimate household survival mechanisms into 'criminal activities,' brands households as 'bad citizens' or forces households to restrict or compromise other essential service expenditures should be viewed with the highest degree of caution.

\section{How many households are accessing the free basic water utility?}

Research data indicated that $100 \%$ of households, included in the study, were not accessing the FBW utility (benefiting from using less than $6 \mathrm{kl} /$ month). Noting that $10.1 \%$ of households (see Table 1) had 2 members or less and therefore should, by indication of Msunduzi Municipality statistics, be accessing the utility of FBW, numerous possibilities exist to account for the $100 \%$ statistic: households were receiving FBW but were consuming more than $6 \mathrm{k} \ell$ therefore they were unable to access its utility; households were uninformed $(81.2 \%$ of households knew nothing about FBW and hence did not know if they were receiving it or not) or households were not paying municipal consolidated bills (38.2\% of households indicated that no member took responsibility for payment, therefore those particular households may not have known whether they were receiving their water for free or not as bills where left unopened or promptly disposed of). Unfortunately, Msunduzi municipal statistics on how many lowincome households were accessing the utility of FBW were neither available nor accessible therefore triangulation of research data was not possible. Such municipal statistics would be an invaluable indicator of the success of the FBW policy. Here too, the triangulation of municipal data with DWAF FBW statistics were rendered invalid because although DWAF FBW statistics indicated population coverage, they did not indicate access to the FBW utility which was necessary because of the particular FBW delivery option adopted by the Msunduzi Municipality.

A recent (2005) study, conducted by the same authors, in a community in Msunduzi has, unlike the Masters dissertation, been able to infer access to the FBW utility through improved access to Msunduzi low-income household consumption data. The study conducted in a community with similar socio-economic characteristics as the five areas included in the Masters dissertation, was able to conclude that out of 1091 residential homesteads, only 76 or $6.966 \%$ of these households were accessing the free basic water utility (i.e. consuming 0 to $6 \mathrm{kl} / \mathrm{month}$ ). Of these 76 households, 12 were restricted through restriction devices, thereby bringing the figure down to $5.566 \%$ of all 1091 households potentially able to voluntarily restrict themselves to $6 \mathrm{k} \ell$ and thereby access the FBW utility.

The access to the FBW utility is determined by household consumption patterns and needs (can households or can households not limit themselves to only $6 \mathrm{k} \ell$ ); and the access to water (over and above the $6 \mathrm{k} \ell$ ) is determined by household afford- ability constraints, tariff structure design and the severity of municipal credit control mechanisms. Hence, if households require more than $6 \mathrm{k} \ell$ for their basic water requirements, which is plausible especially for medium-large households, affordability constraints mean that households will either have to use their limited income to pay for additional volumes consumed or restrict their water consumption to $6 \mathrm{k} \ell$ (with implications for health) or consider alternatives to their household supply (difficult in an urban setting with limited alternative water sources, and even more difficult if neighbours are experiencing similar affordability constraints).

The Water Services Act (RSA, 1997: section 4:3c) states, 'that a Water Service Provider may not deny a person access to basic water services for non-payment, where the person proves, to the satisfaction of the relevant water services authority, that he or she is unable to pay for basic services.' What this clause is saying is that households should not be disconnected for nonpayment, if they prove to be truly unable to pay, but at issue here is the concept of 'basic services.' We have indicated that 'basic services' as issued by DWAF are not commensurate with the basic water requirements of the majority of households. Hence, municipalities are allowed to restrict households to a volume of water that may not be commensurate with dignity, well being and productivity. This is problematic, not responsible social and health policy and gains added significance because social research on basic water requirements and the implications of restricted water supplies for households are to-date inconclusive.

\section{Affordability}

Libhaber, the World Bank's senior water and sanitation engineer in Latin America, stated that for water and sanitation tariffs to be socially acceptable, they should not exceed certain payment thresholds of 3 to $4 \%$ of household income, otherwise people will simply be unable to pay (cited by Pauw, 2003). The World Health Organisation and Camdessus \& Winpenny (2003) put the affordability threshold at $7 \%$ and $5 \%$ of total household incomes, respectively.

Basic service expenses for low-income households, included in the study, were approximated and calculated for the following basic services: water $(22.5 \mathrm{k} \ell /$ month$)$, electricity, waste removal and sewage, and were as follows: water costs R109.80 (22.5 k $\ell$ ); electricity costs R200.00; waste removal costs R19.53 and sewage costs R20.75 (service figures did not include monthly arrears repayments). Waste removal and sewage costs are charged at a lower rate for low-income township households- these costs are indicated above. The low-income household basic service expenses were derived from analysing municipal consolidated bills, focus groups with community researchers and community meetings with the wider communities (included in the study). This was necessary as the expenditure data derived from the surveys were generally incomplete and it was necessary to triangulate data with municipal bills to ensure a greater degree of accuracy. The total for the approximated household expenses was R350.08 (refer to Table 2).

Using the following low-income household midpoint categories of income: R300, R900 and R1 600, the proportion of income needed to be spent on all basic service expenditures (R350.08, see Table 3) was the following: $116.69 \%$ of R300, $38.9 \%$ of R900 and $21.88 \%$ of R1 600 . In the first midpoint category (R300), it is evident that service expenditures are greater than available incomes. If the average total income for all areas in the study was used (R932.17), then the proportion of 
income needing to be spent on basic service expenditures was $37.56 \%$. If monthly water costs were isolated then the proportion of income which needed to be spent on monthly water bills (R109.80) was the following: $36.6 \%$ of R300, $12.2 \%$ of R900, $11.78 \%$ of R932.17 (average total income) and $6.9 \%$ of R1 600 . If water and sanitation expenses were added together (averaged at $\mathrm{R} 130.55$ ) then the proportion of income needed to be spent on water and sanitation payments rose to $43.5 \%$ of R $300,14.5 \%$ of R900, $14.0 \%$ of R932.17 (average total income) and $8.2 \%$ of R1 600. These figures are much higher than the socially acceptable tariff rates of 3 to $7 \%$, as stated previously and illustrate the significant affordability problem faced by low-income households (especially low-income households at the bottom of the low-income range who were not receiving social grants). Table 3 excluded arrears repayments, which ranged from R3 000 to R10 000 per household and value-added tax (VAT) at $14 \%$ on service expenses. Both arrears payments and VAT compounded affordability constraints and decreased monies available for other essential and additional needs.

The Msunduzi Municipal Tariff structure does not meet the socially acceptable tariff rates as stated by Libhaber, the World Health Organisation, Camdessus and Winpenny or the tariff principles as stated in the Strategic Framework for Water Services (DWAF, 2003 p33-34). However, such a situation is not exclusive to Msunduzi Municipality. The World Health Organisation, stated that "South Africans are paying too much for their water" and the countrywide study (2002) released by the Department of Provincial and Local Government (DPLG) (see Pauw, 2003), indicated that municipalities are "charging unaffordable and unreasonably high service rates" (cited by Pauw, 2003, 5). The study findings (see Table 3) are consistent with Pauw's (2003) findings that poor households in South Africa pay up to $40 \%$ of their incomes on water and electricity and further consistent with a statistically representative national survey, completed in July 2001, which sampled 2520 low-income households from across South Africa, and found that basic service charges typically represent a quarter to a half of total household income for $57 \%$ of the households surveyed (Bond, 2001). The median cost for water, electricity, sewerage and refuse removal services ranged from R224 to R400/month (Bond, 2001).

The basic service demands of Msunduzi's low-income households, left little monies for other essential needs, e.g. rent, food and domestic expenses, schooling and training, transport, sanitation and hygiene requirements, medicines and emergency funding. Additional needs might include life and medical insurance, burial and pension schemes and furniture repayments. Essential and additional needs added to the basic service expenditure equation left households struggling to balance their daily needs with compulsory payments to secure basic services often not being made. Basic service expenditures were relatively uniform for many low-income households. The amount of remaining household income available for household wellbeing, dignity and productivity, among others (total household income - basic service expenditures $=$ remaining household income) was influenced by household size, number of children and scholars, and ill persons. Non-payment rates stood at $65.1 \%$ (for all households included in the study) indicating that payments for water services, although voiced as a critical service, often had to be forfeited to ensure that other essential needs were met. Such survival mechanisms were made possible owing to the non-implementation of punitive measures (apart from rising arrears), by the Msunduzi Municipality for households that defaulted on their water service payments. High non-payment rates presented the Msunduzi Municipality with significant cost- recovery challenges and resulted in escalating household service debt, uncertainty and vulnerability.

The majority of households (95.1\%) indicated that their water charges were unaffordable. This response, by households, is the result of DWAF's interpretation of making 'affordable' synonymous with 'free'. Households consuming more than $6 \mathrm{k} \ell$, have to pay for their first $6 \mathrm{k} \ell$ 'free water' and additional water consumed at the standard tariff rate. However, the standard tariff rate is not affordable for the majority of low-income households (see section below). The purpose of differentiating free from affordable is that water legislation places a duty on the state to provide affordable water (Rudin, 2004). The Water Services Act (RSA, 1997: para 11) states that, 'every water services authority has a duty to all consumers or potential consumers in its area of jurisdiction to progressively affordable access to water services'. Albeit, this duty of the state is subject to a litany of limitations, one of which that 'the consumer has a duty to pay reasonable charges, in accordance with any prescribed norms and standards for tariffs for water services' (RSA, 1997: para 11).

\section{Tariffs and cross-subsidisation}

Tariffs are the chief source of revenue for water services in South Africa, over $80 \%$ are derived from the sale of water, the remaining $20 \%$ are derived from taxes and subsidies (DWAF, 2002b). Prior to the presentation of the tariff structure as implemented by the Msunduzi Municipality, it is useful to consider 3 relevant principles, clauses and/or regulations:

- Tariffs are proposed to promote financial and environmental sustainability and are based on the "principles of equity, proportion to use (amount users pay should be in proportion to use of service), affordability, reflecting costs (costs associated with rendering the service), differentiation (differentiation between different categories of users, debtors, service providers, services, service standards and geographical areas) and transparency" (DWAF, 2002b p37).

- The Water Services Act (RSA, 1997: section 10:4) states that "no Water Services Institution may use a tariff which is substantially different from any prescribed norms and standards;"

- DWAF's Regulations and Guidelines document for the implementation of FBW of August, 2002 (DWAF, 2002a p55:2) states that a rising block tariff structure should include, "three or more tariff blocks...with the lowest consumption block set at the lowest amount, including a zero amount,... and the tariff increasing for higher consumption blocks,... with the highest consumption block set to discourage high water use."

South African municipalities set their own municipal water tariffs (supposedly in adherence with the national tariff principles, legal frameworks, regulations and guidelines).

Because the Msunduzi Municipality adopted the $3^{\text {rd }}$ option of free basic water delivery, tariff structures and the monetary value attributed to each block therefore gain greater significance. The Msunduzi tariff structure (2002/03) had only two tariff blocks: the $1^{\text {st }}$ block $(6 \mathrm{k} \ell)$ was charged at R17.07 (calculated from original $1^{\text {st }}$ pre-FBW block $5 \mathrm{k} \ell$ tariff at R2.29 $+2^{\text {nd }}$ block $6^{\text {th }} \mathrm{k} \ell$ tariff at R5.11 (+inflation) $=\mathrm{R} 17.07$ ) and the $2^{\text {nd }}$ block $(7 \mathrm{k} \ell+)$ was charged at R5.62 (figures provided by Msunduzi Water Department, 2003 and Msunduzi tariffs and charges (2002/2003) refer to Fig. 2). The implementation of FBW saw the tariff structure largely unchanged: the monetary value attributed to the tariff structure remained the same; it was 


\begin{tabular}{|c|c|c|}
\hline \multicolumn{3}{|c|}{ Tariff prior to implementation of FBW } \\
\hline $1^{\text {st }}$ block & $0-5 \mathrm{k} \ell(\mathrm{R} 2.29$ per k $)$ & R11.45 \\
\hline $2^{\text {nd }}$ block & $6^{\text {th }} \mathrm{k} \ell+(\mathrm{R} 5.11$ per $\mathrm{k} \ell)$ & R 5.11 \\
\hline Total for $6 \mathrm{k \ell}$ & $(5 \mathrm{kl}+1 \mathrm{k \ell})$ & R16.56 \\
\hline \multicolumn{3}{|c|}{ Tariff with implementation of FBW } \\
\hline $1^{\text {st }}$ block & $0-5 \mathrm{k} \ell(2.29$ per $\mathrm{k} \ell)=\mathrm{R} 11.45+6^{\text {th }} \mathrm{k} \ell(\mathrm{R} 5.62)(\mathrm{R} 5.11+$ inflation $)$ & R17.07 \\
\hline \multicolumn{2}{|c|}{ Total for $6 \mathrm{kl}$ FBW } & R17.07 \\
\hline $2^{\text {nd }}$ block & $7^{\text {th }} \mathrm{k} \ell+(\mathrm{R} 5.62$ per $\mathrm{k} \ell)$ & R 5.62 \\
\hline
\end{tabular}

Figure 2

Msunduzi municipal derivation of free basic water tariffs (Msunduzi Water Department, 2003)

only the parameters that changed to incorporate an additional kilolitre (Msunduzi Water Department, 2003). Households consuming less than $6 \mathrm{k} \ell$ of water per month, benefited from the introduction of the FBW policy; however, the majority of households, consuming more than $6 \mathrm{k} \ell$, saw their water bills largely unchanged. The Msunduzi tariff structure did not provide an adequate stepped block tariff structure with the implication that low-income households (consuming more than $6 \mathrm{k} \ell$ ) fell into the $2^{\text {nd }}$ consumption block. It can be argued that although the tariff structure underwent minor changes (addition of extra $1 \mathrm{k} \ell$ into subsidised block), the $2^{\text {nd }}$ consumption block was proportionally higher than the $1^{\text {st }}$ consumption block. Therefore with annual water tariff increases (of between 8 to $10 \%$ ), the $2^{\text {nd }}$ consumption block has become increasingly unaffordable for low-income households. The tariff structure, with the advent of FBW, had in affect brought no resolution to the affordability constraints facing low-income households, requiring more than $6 \mathrm{k} \ell$ per month and in many cases actually exacerbated affordability constraints.

The tariff principles as issued by DWAF (2002b) were not being upheld by the Msunduzi Municipality. This has been verified by the experiences of Msunduzi's low-income households. Tariffs were inequitable: the poorly equated tariff structure provided limited steps for cross-subsidisation. Low-income and low-consumption users (using $22.5 \mathrm{k} \ell$ per month) received no differentiated concessions, as tariffs were not comparable with use. Tariffs were not implemented according to differentiated water system connections (in-yard or in-house). All households, regardless of water system connection, paid the same tariff for their water service. Tariffs were not affordable: low-income households struggled to pay their water bills. The tariff structure worked on the assumption that all low-income households were accessing the lifeline tariff provided by FBW. This was an inaccurate assumption. Low-income households consuming more than $6 \mathrm{k} \ell$, remained firmly set in the $2^{\text {nd }}$ consumption block, thereby received no subsidisation benefits.

Cross-subsidisation of the poor, by differentiating between social (domestic), economic (commerce, industry and agriculture) or regional group users and charging them accordingly, is generally regarded as a desirable redistributive, accessibility and affordability objective of water service providers (Hall, date unknown). Inaccurately calculated tariff structures decreased cross-subsidisation options from high to low consumers, rich to poor and industry to domestic users. The 2002/03 Msunduzi industrial water tariffs were $\mathrm{R} 5.86 / \mathrm{k} \ell$ and the sewage tariffs were: R2.95 \{0 to $400 \mathrm{k} \ell\}, \mathrm{R} 2.76\{401$ to $1000 \mathrm{k} \ell\}$ and $\mathrm{R} 2.28$ $\{1001 \mathrm{k} \ell+$, subject to a maximum charge of R11 881 per month (Msunduzi Accounts and Billing Department, 2003). Here it is useful to note that although industrial tariffs are slightly higher than domestic tariffs, the difference is not sufficient for optimal industrial-domestic cross-subsidisation. Furthermore, the uniform cost per kilolitre offers no disincentives for high or indeed excessive consumption and therefore little motive to recycle water. Of greater significance is the industrial sanitation tariff structure, which operates on a decreasing tariff scale thereby negating water tariff cross-subsidisation benefits (if any) transferred to domestic users. The "polluter pays" principle is not reflected in the industrial sanitation tariff, which would further burden the municipality, as the municipality would have to fit the bill for clean-up operations in the event of industrial pollution and with no inbuilt revenue plan, the domestic user would see his/her tariffs increase (Rudin, 2003). The Msunduzi Industrial Tariff goes against natural resource protection including national policy, which recommends that industrial tariffs should at least recover the full direct financial costs and may include externalities including, where appropriate, the average incremental costs that would be incurred to increase the capacity of water and wastewater infrastructure to meet an incremental growth in demand (DWAF, 2003). The inflexible tariff structure, with little space for cross-subsidisation, had in effect brought no resolution to the affordability constraints facing low-income households.

\section{Water meters}

The municipality, as a tool to measure and monitor household water consumption and provide the FBW allocation, used water meters. The majority of households $(94.9 \%)$, in the study, were metered. The municipality maintained the meters and monitored household monthly consumption via municipal meter readers who documented monthly household meter readings. If understood by households, meters could be a valuable tool for selfmonitoring household consumption, checking average volumes consumed against water bills and detecting water leakages.

Most of the households (81.8\%) were not satisfied with the way meters were monitored by municipal meter readers. Their dissatisfaction was attributed to the manner in which their meters were read (by municipal meter readers) and their (the households) general lack of understanding on how meters operate. Households indicated that municipal meter readers did not read the meters frequently, readings were inaccurate or estimated (resulting in varying water costs per month), households were sceptical regarding the ability of municipal meter readers to read the meters accurately (confounded when meters were covered in dirt and when frogs, slugs etc. were present) and poor community acceptance of meters and municipal meter readings existed. Where meters were housed in-yard, municipal meter readers claimed that they did read the meters but household members were often away at the time of reading (hence the municipal meter readers could not be monitored or witnessed) or the meter readers were scared of household dogs and were afraid of entering yards. Households voiced that they required basic information on how meters were operated, how the "dials" were read and how the readings corresponded with the monthly bills to ensure 
that they could monitor their water usage and check that they were not being overcharged. In addition to the confusion on the operation of meters, meter readings were not consistently taken on the same day each month so municipal consolidated bills did not reflect a constant date, time duration or volume used. This compounded the difficulty of households to monitor meters and billing. Meters, connected to an efficient computer programme, could be managed effectively. However, the administrative department stated that the current computer systems were outdated, with the implication that monitoring was difficult and current reliable statistics were lacking.

Despite the widespread dissatisfaction of households to meters, a large percentage of households (68.8\%) indicated that meters were still a good tool in service delivery. However, when asked to provide possible meter alternatives, $85.9 \%$ of households suggested non-specific alternatives. This emphasised the perceived uselessness of meters for household monitoring in the absence of information and the necessity to find socially acceptable alternatives accompanied by usable consumer information.

\section{Leakages and water demand management}

Most households (77.1\%) reported leakages, after the meter position (this figure was consistent with the findings by the Msunduzi City Engineers, 2003). See Table 3 and Fig. 2. Leakages were present at one or more of the following sites: at the meter, after the meter (on the pipe connecting the tap), at the tap, on the pipe connecting the toilet and in the toilet. This was a significant concern of households and was shared by the Msunduzi City Engineers (2003). Leakages were not dealt with and continued to drip, spurt or gush. Leakages, as indicated by households, could be attributed to shoddy workmanship or inferior materials used by contractors, ageing systems, high pipe pressure or poor maintenance and management. The inefficient or delayed fixing of leakages by households could be due to: lack of personal capacity to fix leakages, lack of awareness as to the extent of water lost through even 'small leakages,' household affordability and time constraints or indifference owing to the fact that many households were not paying for the water. The inefficient or tardy fixing of leakages by municipalities could be attributed to inefficient notification systems, a lack of budgetary or financial support for maintenance projects, insufficient staff or the low prioritisation of maintenance operations on a political level. Table 3 depicts the number of households experiencing leakages (at the meter, after the meter \{at pipe connecting the tap\}, at the tap, on the pipe connecting the toilet and in the toilet) per area.

Leakages that were not dealt with promptly and continued unabated presented households with a challenging affordability problem. If households could not cover the loss, then municipalities assumed the economic burden, which through the cycle of responsibility, were transferred to households through higher tariffs thereby increasing the financial burden of households. The Msunduzi City Engineers (2003) expressed that they were mandated by the Msunduzi Municipality to fix leakages pre- and at the meter but that they were also endeavouring to assist households and would repair post-meter leakages but would charge for their services, which could be paid for through instalments (see Fig. 3). This avenue was explored via the Msunduzi Water Department toll-free telephone number: 0800 001868, and through additional correspondence with the Msunduzi City Engineers. Here it emerged that the Water Department did fix pre-meter and at-meter leakages but did not fix post-meter leakages (see Fig. 3). The rationale for this was proffered as (a) legal ramifications, if something went wrong (e.g. a burst pipe in-house); (b) the high

\begin{tabular}{|l|c|c|c|c|}
\hline \multicolumn{5}{|c|}{ TABLE 3 } \\
Number of households experiencing leakages \\
per study area \\
\hline Study areas & \multicolumn{2}{|c|}{ Were households experiencing leakages? } \\
\cline { 2 - 5 } & No & Yes & $\begin{array}{c}\text { Total } \\
\text { n=306 }\end{array}$ & $\begin{array}{c}\text { Total number } \\
\text { of households } \\
\text { experiencing } \\
\text { leakages \% }\end{array}$ \\
\hline Imbali (Unit 1) & 3 & 50 & 53 & $94.3 \%$ \\
\hline Imbali (Unit 2) & 8 & 29 & 37 & $78.4 \%$ \\
\hline Haniville & 27 & 59 & 86 & $68.6 \%$ \\
\hline Sobantu & 27 & 45 & 72 & $62.5 \%$ \\
\hline Thembalihle & 5 & 53 & 58 & $91.4 \%$ \\
\hline Total & 70 & 236 & 306 & $77.1 \%$ \\
\hline
\end{tabular}

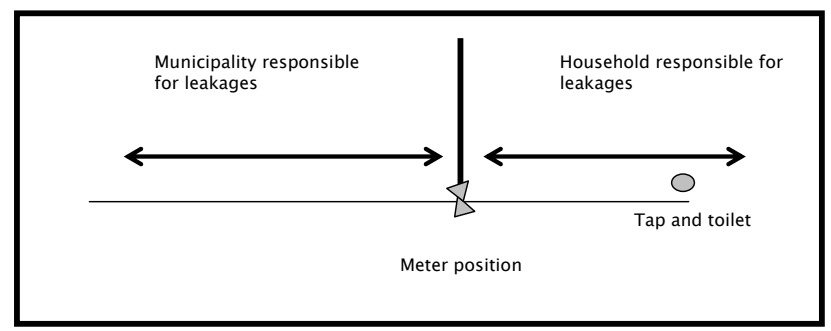

Figure 3

Municipal and household leakage responsibilities (Msunduzi City Engineers, 2003)

cost of insurance expenditures covering all households with post-meter leakages in securing against household damage in event of (a) and; (c) an already overburdened workforce, limited finances, human resources and innovative systems. This left households with few options, with the implication that most leakages continued to do just that...leak. Although the reasons for not fixing post-meter leakages is relatively convincing, one would believe that other approaches could be taken? Possibly the use of indemnity forms (if legal ramifications/insurance is at issue); the employment of more staff (cost-benefit of water lost vs. cost of extra staff) or even creative initiatives such as 'water leaks projects' (community leakage projects), such as that initiated in Harare, Khayelitsha.

"Water service authorities should consider providing assistance for the repair of plumbing fittings as this is a cost-effective intervention in reducing water service costs to both consumers and the water service provider (DWAF, 2002b)" Water service providers should adopt a systematic approach to reduce water leakages, while considering costs and benefits through pressure management, utilising technical innovation, and developing management information systems to provide relevant and timely information (DWAF, 2002b). As depicted in Fig. 2, the municipality's responsibility ended at the household meter. Noting that contractors connected the fittings from the meter to the tap, and that monitoring of contractors was poor (reported by households and Msunduzi NGO, 2003), it is critical that such a service exists.

The development of management information systems, identified by DWAF (2002b), was not adequately implemented by the Msunduzi Municipality and the current system was not consistent with a lateral approach necessary for an effective management system (Shepherd, 2001). Until an effective water demand management plan is implemented, households will continue receiving inflated water bills and in the case of inability to pay, the municipality will continue recouping losses for unac- 


\begin{tabular}{|l|c|c|c|c|}
\hline \multirow{4}{*}{$\begin{array}{l}\text { Household satisfaction (per study area) towards } \\
\text { Water Service Provider (Msunduzi Municipality) }\end{array}$} \\
\hline Study area & \multicolumn{5}{|c|}{$\begin{array}{c}\text { Were households satisfied with the } \\
\text { water service provider? }\end{array}$} \\
\cline { 2 - 5 } & No & Yes & Total & $\begin{array}{c}\text { Total number } \\
\text { of households } \\
\text { satisfied (\%) }\end{array}$ \\
\hline Imbali (Unit 2) & 16 & 18 & 34 & $52.9 \%$ \\
\hline Imbali (Unit 1) & 23 & 23 & 46 & $50.0 \%$ \\
\hline Haniville & 11 & 76 & 87 & $87.4 \%$ \\
\hline Sobantu & 8 & 62 & 70 & $88.6 \%$ \\
\hline Thembalihle & 33 & 24 & 57 & $42.1 \%$ \\
\hline Total & 91 & 203 & 294 & $69.0 \%$ \\
\hline
\end{tabular}

counted water usage through the transfer of the financial burden to households through increasing tariffs which low-income households will struggle to pay.

\section{Household satisfaction levels}

Household satisfaction levels towards water service delivery were obtained as a valuable indicator to provide a holistic summary of municipal water service delivery. However, the responses were indicative of cautious responses, owing to high non-payment rates and low-levels of participation within the water delivery system. Nevertheless, responses provide important data on which improvements could be founded.

Household satisfaction responses were in the majority positive, with $69 \%$ of all households indicating their satisfaction with municipal water service delivery (see Table 4). However, satisfaction levels differed greatly between study areas and affirmative responses were generally attributed to the municipality not implementing broad-based punitive measures for non-payment and extending water services to those households not formerly connected to the reticulation system. Satisfaction levels were therefore based on access and not service delivery efficiency. Furthermore, households displayed caution in challenging the municipality for fear that it might lead to disconnection or discrimination. The cautionary principle was adopted because of two factors: many households were not paying for their water and feared that their rights to criticise the municipality were limited and their level of participation in the water sector was poor. Household dissatisfaction with the municipality was attributed to the following: poor service quality, poor channels of communication, delays in responding to problems, old or inferior reticulation systems, delayed leakage responses, meter-reading concerns, affordability constraints, inadequate arrangements or warning in cases of service disconnections (during system maintenance) and threats of disconnection for non-payment.

Households in the study provided the following suggestions on how the Msunduzi Municipality could improve service delivery (prioritised in descending order): Local community involvement and improved communication (28.1\%); improving service delivery- non-specific (24.8\%); repairing and replacement of delivery systems (11.2\%); improving water affordability $(8.3 \%)$; meter information, improved meter reading or monitoring technology change (7.8\%); no changes required (5.8\%); improving access to water $(4.9 \%)$; in-house connections $(4.9 \%)$; information and education (2.9\%); and implementing a flat monthly charge (1.5\%).

Perhaps the most important aspect to take from household responses is the need for increased community engagement with the water service delivery system. Such an engagement process would require the access to relevant water-related information. Households identified the following information, deemed to be valuable for their being proactive and informed contributors to an effective water delivery system:

- All aspects of free basic water and tariff structures; how the water system and administrative system worked

- Household water conservation and water pollution

- How meters worked, how meters and municipal consolidated bills were read and how to read meters in conjunction with municipal consolidated bills

- Affordability and payment options.

\section{Municipal administration}

The water service reporting channels used by households to report leakages, water-related issues, or to access information were though ward committees, councillors, informed and capacitated community members or municipal authorities. The community councillor was the prime channel taken by households (through their ward committees) to report their water-related issues. However, responses were frequently delayed or absent. The preferred channel used by households (44.7\%) was through local municipal authorities via telephone or direct contact. However, many households were forced to make arrangements within social circles or simply ignore the problem, as official reporting channels were often inefficient or unavailable. It was evident that dissatisfaction existed regarding the current system. Community authorities often exhibited a low level of interest, capacity or will to take issues forward and municipal authorities were approached with scepticism (by households) because of their (municipal authorities) high level of bureaucracy, inaccessibility or lack of social (customer) skills. Households reported being embarrassed or humiliated when approaching municipal authorities for help. Interestingly, women where the major pursuers of assistance from municipal authorities because men were simply not prepared to 'waste their time in queues or to be treated like naughty children.' All the above contributed to the disempowerment of households and a poor acknowledgement by the relevant authorities of how important it was that communication channels were open and effectively maintained.

There were significant co-operation challenges faced within the local Msunduzi Municipality's administration, treasury, engineering and water departments. It was attributed, as described by one official as a 'silo-effect' whereby different departments did not communicate with one another effectively and conflict of interests often arose (personal communication with Msunduzi Water Department official, 2003). This frequently resulted in projects not being provided sufficient financing, political backing or social prioritisation, which culminated in inefficiencies and uninformed decisions. Furthermore, the municipal water department and city engineers stated that there was substantial political interference in budgetary allocation and the prioritisation of water issues. There were communication barriers within decision-making forums, whereby the recommendations of diverse departments seldom were synthesised into integrated strategies (Msunduzi City Engineers, 2003). This resulted in the municipal council ("rubber-stampers") taking decisions from uninformed positions and ignoring critical aspects, which ultimately meant that adopted strategies were neither holistic nor efficient. Community platforms, for public input into decision making forums, thereby providing a critical voice from the ground, were either absent or ineffectively utilised. This resulted in a system with no feedback from citizens, 
who were experiencing the implications of water service delivery strategies, thereby relying heavily on so-called, 'technical and administrative expertise' with little social or grassroots experience. Ultimately such an administration would find it difficult to distance itself from an emerging water and indeed municipal services crisis.

\section{Conclusions}

The study conclusions implied that local and national policies and strategies that were purported to ensure that the basic service requirements and rights of low-income households were upheld, actually compounded the socio-economic constraints and compromised the human rights, justice, equity and dignity of Msunduzi low-income households. Because local and national policies and strategies had failed to promote lowincome household affordability and access to their basic water requirements, the financial ability of households to pay for their services determined their access. This might have been acceptable if low-income households were able to pay for their services and influence the way in which water services were delivered and managed, but limited financial flexibility and restricted political manoeuvring space impeded the input of low-income households into decision-making fora. High unemployment levels, medical expenditures and burial costs (compounded by HIV/AIDS), rising basic food costs, large families, school and training fees and transport charges made it difficult for households to afford basic service expenditures. Concurrently communities were being increasingly marginalised from decisionmaking and engagement processes. Local and national policies and strategies should have provided a framework in which lowincome households were able to secure basic services to sustain their livelihoods. Instead, policies and strategies contributed to the financial quandary that low-income households were struggling to overcome.

The free basic water policy failed to meet the basic water requirements of Msunduzi low-income households, with the implication that low-income households were unable to obtain the FBW utility, compounding access and affordability constraints. Low-income households exceeding the FBW allocation of $6 \mathrm{k} \ell$, were expected to pay the full cost of their water consumption at expensive tariffs. The Msunduzi Municipality's limited stepped tariff structures ensured that low-income households fell into the steep second block thereby negating cross-subsidisation possibilities. There was no cross-subsidisation between domestic and industrial users. In fact, industrial tariffs rewarded users for high consumption by providing industry cheaper per unit rates thereby compromising social and environmental sustainability. Meters were poorly monitored and managed by the Msunduzi Municipality. Water service-related information and the value of household monitoring of consumption, via water meters, were not explained to households. Water demand management was poorly prioritised with the implication that the financial and environmental sustainability of the resource was compromised and compounded the financial constraints of the Msunduzi Municipality and households. Information management systems were lacking, inadequate or inaccessible which restricted reporting and querying channels and delayed the prompt address of issues. Municipal administration failed to communicate sufficiently within its own departments, took decisions without consolidating all relevant information at hand and rarely ventured to seek or listen to the experiences of its citizens to its water service delivery strategies.

\section{Policy recommendations}

Recommendations are suggested for local and national policy, strategy and implementation reforms relating to the following issues: amended free basic water policy, affordability mechanisms and tariff structures, water meters, leakages and water demand management, municipal administration and political platforms. Recommendations highlight popular approaches through public consultation, engagement and information dissemination, extensive data collection, reviews, evaluations, audits, amendments and the implementation or intensification of regulation and monitoring mechanisms.

\section{Free basic water}

A national FBW evaluation should be implemented to clarify the accessibility of the FBW utility. This evaluation should give equal privilege to qualitative methodologies as it does to quantitative methodologies, e.g. DWAF should move beyond measuring the number of municipalities implementing the FBW policy thereby directly deducing populations benefiting and instead look to more qualitative measures that indicate whether households (in the case of Msunduzi) are actually accessing the FBW utility and whether the FBW policy is making a contribution to lessening the economic burden of households. The basic water requirements for health, well-being and satisfying productive, sustainable livelihoods should be scientifically and socially assessed. Factors affecting household consumption should be accessed, i.e. household size, water usage characteristics of dependants (number of dependants affects volumes consumed because of frequent clothing washes and hygiene practices); ill persons in the household (specifically people living with HIV/ AIDS whose hygiene goals were essential for well-being and present decreased options for sharing water); water volumes used for flush toilets (using 9 to $19 \ell$ per flush and increased frequency of flushes in case of diarrhoea and menstruation); differentiations between weekday and weekend (water usage doubled - increased washing, more persons present and visitors); water for productive usage and multiplier-effects; water for emergencies (medical and fire hazards) and cultural practices. A parallel process should be implemented to create platforms whereby the experience of low-income households to FBW could be voiced. The outcomes of the evaluation, basic water requirements and low-income experiences to FBW should be integrated and the FBW policy reformed to achieve its affordability, poverty alleviation, gender, equity and public health objectives.

\section{Affordability mechanisms and tariff structures}

A national tariff audit should be initiated to assess if municipal tariffs are set in accordance with DWAF tariff principles. DWAF should enforce tougher regulations on municipalities that ignore national tariff principles. Progressive redistribution tariff systems, which draw on the input of communities, should be implemented to meet social, equity and affordability objectives, while promoting the sound use of the resource and ensuring amicable cross-subsidisation from high to low volume users in Msunduzi. Communities should be provided the space to engage directly in tariff decisions. Amended tariff structures should take into account all associated low-income household service expenditures (electricity, rates, rent, food, school and training fees, transport and medical expenses) and be brought in line with recommended payment thresholds ( 3 to $7 \%$ of household income). Affordability constraints of low-income households should be 
alleviated through implementing equitable tariff structures and amicable crosscutting cross-subsidisation measures.

The Msunduzi Municipality's tariff structure (2 blocks) and money attributed to each block (very expensive compared to other municipal tariffs) should be investigated with immediate effect by DWAF and the relevant changes speedily implemented. This investigation into tariffs should be extended to all municipalities, on the findings of such an investigation, regulations should be vigorously exercised. The effects of water boards as contributors to high tariff charges should not escape such an enquiry; DWAF should start with Umgeni Water.

Stepped tariff structures could be modelled on the following system: $1^{\text {st }}$ block $(15 \mathrm{k} \ell)$, amended free basic water; $2^{\text {nd }}$ block (upper limit $25 \mathrm{k \ell} /$ household $\cdot \mathrm{month}$ ), lifeline tariff; $3^{\text {rd }}$ and $4^{\text {th }}$ block to account for high-volume consumption (consistent with current household consumption patterns). The FBW allocation should be calculated at zero cost to low-income households; the lifeline tariff should be calculated at an affordable and socially acceptable rate; and the third and fourth blocks should be much steeper, thereby providing disincentives for high or wasteful consumption and be calculated at an economic rate. Only if the citizen falls into the third or fourth tariff, and hence becomes a high volume consumer, using more than the amended FBW and lifeline tariff, should they pay for the FBW usage.

\section{Water meters}

There should be a national audit reviewing the type, utilisation, value, cost and acceptance of meters and their value in terms of cost-benefit to municipalities and households. Should the results of the audit show that meters are an acceptable monitoring mechanism and show a favourable cost-benefit to municipalities and households then the following should be implemented (based on the experiences of the households included in the study): information should be distributed to households on how meters function, how households can utilise meters as a household consumption monitoring mechanism and how to use the information from the meter readings in conjunction with municipal consolidated bills. This would transfer monitoring control to households. Information on how to read municipal consolidated bills should be distributed to promote ease of use. Furthermore, the date that the municipal meter reading took place should be consistent with the meter reading date appearing on municipal consolidated bills. This would assist households in triangulating billed data, with their household meter monitoring data, with the implication that consumption volumes and the associated costs may be more acceptable to households, whilst providing the space for querying any irregularities. Households should be encouraged to enter the monthly meter readings into household logbooks as a triangulation mechanism.

Another option in the meter discourse is of implementing bulk meters instead of individual household meters. Why does council continue implementing household meters if the possibility exists that meter readers do not read them accurately (are poorly trained or unable to access the meters) and households cannot use them as a monitoring tool owing to lack of information? Are bulk meters (that service approximately 50 households) not a better option (Veotte, 2003)? Costs in implementation are relevant because bulk meters would save money (installation costs R1 000 vs. R300*50 = R15 000 (including service and monitoring charges); administration and meter reader costs, time and achievement of the same goal (possibly more accurately as meter readers could read fewer meters and read them consistently as time constraints would be lessened; hence reading 1 bulk meter vs. 50 individual household meters). Bulk meters offer a considerable saving; however, individual self-monitoring would be negated, as all 50 households would split the consumption costs equally. The opinion of the authors is that if the current technology is pursued (individual meters) than it must be supported by efficient computer technology, consumer information and social acceptance.

\section{Leakages and water demand management}

A comprehensive national household water leakage audit should be implemented. District meters should be implemented in all communities indicating water lost per area (community level) and the monetary values lost to municipalities in real costs. Water saving scenarios should be implemented in terms of the cost-benefit of implementing water demand management policies which examine actual water consumption in areas, water losses, monies lost over one month, one year and five years; and include the population served, population growth, and the implication of all the factors on water-service resource expansion and municipal and national government finances. Numerous possibilities exist in addressing the leakage challenge e.g. increased monitoring, regulation, quality control and accountability of contractors; proper pressure management (during 24:00 to 04:00 to decrease water losses); improved leakage management; fast-track leakage response; community plumbers (via water leaks projects); and timely information systems (Msunduzi City Engineers, 2003).

A comprehensive national and local household water demand management policy should be implemented. The water demand management policy should cover all water systems, including meter to tap leakages. It is important to apply the benefits of lateral thinking to the operation and management of water delivery systems; hence, cost-benefit approaches should be prioritised and not constrained by limited operational budgets and financial constraints (Shepherd, 2001). Through the policy, an information management system should be implemented whereby technical equipment can pinpoint where and when leakages are occurring. Technical teams should synthesise the data and mobilise a leakage management team to address the leakages promptly. A reporting system, whereby households report leakages directly to the technical team, should form a parallel system to that mentioned above. The water demand management policy could assist in creating the space whereby "community water leaks projects" could be initiated. Community water leaks staff should be trained by and work closely with technical teams until all leakage responses and leakage monitoring could be owned and managed by project staff. The municipality should support the project with finance and technical assistance. The project staff members should also be trained in implementing environmental audits whereby they can assist households in identifying water losses as well as ways to conserve water (Cape Town NGO, 2002).

Political will for the prioritisation of water demand management and sufficient financing for community water leaks projects must support options. Financing such a policy and water leakage projects should be mobilised through the Municipal Income Grant for infrastructure (leakage) upgrades and maintenance thereby providing the finances for a proactive rather than a reactive operation (Shepherd, 2001). A proactive response would include the upgrading of old water systems (especially in older townships), regulating and monitoring municipal contracts and quality standards. A complementary 3 -year grant could be initiated that serves the same purpose as the Municipal Income 
Grant, but is substantially larger and moves onto other municipalities after 3 years; hence providing a financial boost for municipalities to ensure that their water systems are effectively managed and maintained.

\section{Municipal administration and political platforms for community engagement}

Efficient and effective administrative systems are imperative for an effective water service delivery framework. The administrative and technical capacity of personnel should be increased and where necessary, support staff numbers should be increased. Technical equipment should be updated (Msunduzi Administration, 2003). Information management systems and relevant statistical databases should be implemented and maintained (DWAF, 2002b). DWAF should dedicate sufficient resources to municipalities to ensure that public administrative systems are ready and capacitated for their new decentralised roles. A skills and technical audit should be initiated and the gaps in public administrative systems should be bolstered, with a sufficient and diversified technical and personnel base. Administrative systems should be accessible and receptive to the public.

The study revealed fundamental problems concerning the "top-down approach" system of municipal decision-making. Platforms for information and experience sharing should be created to ensure that the experience from the ground is incorporated into formal and informed decision making processes. Communication channels between and within all stakeholders should be significantly enhanced and the capacity of all stakeholders to engage in fundamental issues should be improved. The political space should be available and accessible to all citizens. There should be a national review on the political nature of community structures and systems should be adapted to ensure that all people, regardless of political affiliation, are represented equally.

Information on water systems management and municipal structures should be available and accessible to all to promote engagement with decision-making structures. Municipal plans should be implemented to promote popular administration through public consultation, participation and information dissemination and extended to all aspects of water service delivery, e.g. budget prioritisation by communities. Central to popular involvement is the right to access information for the exercise or protection of rights (RSA, 1996: section 32.1), which should be upheld and available to all, without restriction.

\section{Update}

Notable changes have taken place in the Msunduzi Municipality post-study: initiation of indigent policy, tariff increases (and unchanged tariff structure) and broad-scale restrictions/credit control policy.

\section{Indigent policy}

To date more than 17000 Msunduzi households have been registered as indigents (automatic and applied). Water tariffs for indigent households $(2005 / 2006)$ are the following: 0 to 6 $\mathrm{k} \ell$ (free); 7 to $12 \mathrm{k} \ell(\mathrm{R} 2.99 / \mathrm{k} \ell$ ) and $13 \mathrm{k} \ell+(\mathrm{R} 7.34 / \mathrm{k} \ell)$. Indigent households are automatically restricted to $6 \mathrm{k} \ell$ or $12 \mathrm{k} \ell$; however, they may apply for more water, with the flow-limiting device adjusted to requested amount. The indigent policy is still in its infancy, more research is required to assess its benefits to low-income households.

\begin{tabular}{|l|l|l|l|l|}
\hline \multicolumn{5}{|c|}{ TABLE 5 } \\
\hline Msunduzi water tariffs post-study \\
\hline Ysunduzi water tariffs \\
\hline $0-6 \mathrm{k} \ell$ & $\mathrm{R} 17.07$ & $\mathrm{R} 18.78$ & $\mathrm{R} 20.65$ & $\mathrm{R} 22.30$ \\
\hline $7 \mathrm{k} \ell+$ & $\mathrm{R} 5.62$ & $\mathrm{R} 6.18$ & $\mathrm{R} 6.80$ & $\mathrm{R} 7.34$ \\
\hline Industrial & $\mathrm{R} 5.86 / \mathrm{k} \ell$ & $\mathrm{R} 6.45 / \mathrm{k} \ell$ & $\mathrm{R} 7.10 / \mathrm{k} \ell$ & $\mathrm{R} 7.67 / \mathrm{k} \ell$ \\
\hline $\begin{array}{l}\text { Msunduzi } \\
\text { 2005/06) }\end{array}$ & Tariffs and Charges (2002/03; 2003/04; 2004/05; \\
\hline
\end{tabular}

\section{Post-study water tariffs: a comparison}

The Msunduzi tariff structure has not changed since 2002/03 (i.e. $1^{\text {st }}$ consumption block 0 to $6 \mathrm{k} \ell$ and $2^{\text {nd }}$ consumption block $7 \mathrm{k} \ell+$ ). However, water tariffs have increased between 8 to $10 \%$ each year and it is useful for the reader to note the substantial burden these tariffs have on low-income households (refer to Table 5).

\section{Restrictions and credit control policies}

The installation of water restriction devices into the water supply systems of 'bad debtor households' have steadily increased since 2002/03. The City Engineers indicate that approximately 60 restriction devices are installed every day or 1200 every month (Msunduzi City Engineers, 2005). The chief device used is the 'restriction washer'; however, different types of flow-limiting devices are being experimented with. Households unable to pay for their water consumed, are now liable for restriction or face other punitive measures for non-payment e.g. the handing over to lawyers, minimum payment arrangements or repossession of furniture or eviction. The Msunduzi Municipality has also initiated the consolidation of all services onto one monthly bill (including the monthly payment of rates). Monies, paid each month go to paying the oldest debt; therefore (as an example) households prioritising the payment of water expenses but foregoing the payment of rates, may still face water restrictions.

\section{Acknowledgements}

We thank the National Research Foundation (NRF) for financial support and the reviewers for their insightful comments.

\section{References}

AFRICAN NATIONAL CONGRESS (ANC) (1994) Reconstruction and Development Programme: Water and Sanitation: 2.6. Umanyano Publications, Johannesburg, South Africa.

AFRICAN NATIONAL CONGRESS (ANC) (2000) ANC Campaign Promise, 2000 Municipal Elections [WWW document] URL http://www.anc.org.za/elections/local00/manifesto/manifesto.html (accessed 2 February 2004).

ASHEESH M, RUOHONEN K and AL-OTAIBI M (2003) Water balancing in sharing and evaluating scarcity of water resources in national and international river basins. In: Tecnologi'a De La Intrusión De Agua De Mar En Acul'feros Costeros: Países Mediterra'neos. Madrid.

ATKINSON D (2002) Local Government, Local Governance and Sustainable Development: Getting the Parameters Right. Integrated Rural and Regional Development Research Programme, Occasional Paper 4. Human Sciences Research Council Publishers, Cape Town, South Africa.

BOND P (2001) Services for All: national survey on service delivery. Occasional Papers Series: 3. Municipal Services Project, Gauteng. 
CAMDESSUS M and WINPENNY J (2003) Financing Water For All. Report of the World Panel on Financing Water Infrastructure, in collaboration with World Water Council, 3rd World Water Forum and Global Water Partnership. Marseilles, France.

CAPE TOWN NGO (2003) Anonymous civil society water stakeholder. Personal communication.

COETZEE C and NEWPORT-GWILT V (2003) Young, jobless and black. The Witness 28 July, 2003. [WWW document] URL http:// www.witness.co.za/showcontent.asp? $\mathrm{id}=17054$ \&action $=$ full

COSATU \& SAMWU (2003) Joint submission by COSATU and SAMWU on the Draft White Paper on Water Services, 2002. Presented to the Department of Water Affairs \& Forestry, 29 February 2003.

DEPARTMENT OF LOCAL AND PROVINCIAL GOVERNMENT (DPLG) (2003) Free Basic Water and Division of Revenue. Presentation to the Portfolio Committee on Water Affairs and Forestry, Cape Town, 4 June 2003.

DEPARTMENT OF WATER AFFAIRS AND FORESTRY (DWAF) (2002a) Regulations and Guidelines. Department of Water Affairs and Forestry, Pretoria, South Africa, August 2002.

DEPARTMENT OF WATER AFFAIRS AND FORESTRY (DWAF) (2002b) Draft White Paper on Water Services: Water is Life, Sanitation is Dignity. Draft for Public Comment. Department of Water Affairs and Forestry, Pretoria, South Africa.

DEPARTMENT OF WATER AFFAIRS AND FORESTRY (DWAF) (2002c) Free Basic Water Implementation Strategy. Version 2. Guideline Document. Department of Water Affairs and Forestry, Pretoria, South Africa.

DEPARTMENT OF WATER AFFAIRS AND FORESTRY (DWAF) (2003). Strategic Framework for Water Services. Department of Water Affairs and Forestry. Pretoria, South Africa.

GLEICK PH (1998) The human right to water. Water Policy 1 487-503.

HALL D (date unkown) Water in Public Hands. Public Services International Research Unit, University of Greenwich. Commissioned by Public Services International, London. 7-27.

HAZELTON D (2002) Overcoming constraints to the implementation of water demand management in Southern Africa. In: Implementa tion Tools: 3: Water Tariffs and Targeted Subsidies. Adapted from a submission, by Hazelton, for a booklet to be published by the South African Department of Water Affairs and Forestry: Water Conservation \& Water Demand Management guidelines manual for Water Service Institutions. The World Conservation Union (IUCU) study, TSE Water Services, South Africa.

HEMSON D (2004) South Africa's poverty by numbers. Based on paper: Beating the Backlog: Meeting Targets and Providing Free Basic Services. Human Sciences Research Council, South Africa. Mail and Guardian. June 25-July 1 edn. 10-11.

HOWARD G and BARTRAM J (2003) Domestic Water Quantity, Service Level and Health. World Health Organisation. [WWW document] URL http://who.int/water_sanitation_health/diseases/ wsh0302/en (accessed 12 April 2003).

HUMAN SCIENCES RESEARCH COUNCIL (HSRC) (2002) The Crisis of Service Delivery. HSRC Publishing, Tokai.

HUNTER N, MAY J and PADAYACHEE V (2003) Lessons for PRSP from Poverty Reduction Strategies in South Africa. 3rd Meeting of the African Learning Group on the Poverty Reduction Strategy Papers. Economic Commission for Africa. Addis Ababa, Ethiopia, 3-5 December 2003.

KASRILS R (2001) Minister of Water Affairs and Forestry. Debate on the President's State of the Nation Address. 14 February 2001. Parliament, Cape Town (WWW document) URL http://www.dwaf.gov. $\mathrm{za} /$ Communications/MinisterSpeeches/Kasrils/2001/President's\% 20debate $\% 20$ speech $\% 20$ by $\% 20$ Minister $\% 20$ on $\%$ 2014\%20February\%202001.dod (accessed 13 July 2003).

KASRILS R (2003) Minister of Water Affairs and Forestry. Article: Free water not a ploy (20 November, 2003). The Witness. In response to Julie Smith's article: Free water policy is a "mere ploy", 22 September 2003.
KHOSA M (2000) Re-thinking infrastructure policies in the 21st century. In: Khosa M (ed.) Infrastructure Mandate for Change 19941999. Human Sciences Research Council Publishers, South Africa. 176-181.

MBEKI T (2001) President's Speech in Tshwane. Delivered on 10 February 2001. Pretoria, South Africa.

McDONALD D (2002a) The theory and practice of cost recovery in South Africa. In: McDonald D and Pape J (eds.) Cost Recovery and the Crisis of Service Delivery in South Africa. Human Sciences Research Council Publishers, Cape Town, South Africa.

McDONALD D (2002b) No Money, No Service. South Africa's poorest citizens lose out under attempts to recover service costs for water and power. Alternatives Journal 28 (2) 16-20.

McDONALD D and PAPE J (2002). Cost Recovery and the Crisis of Service Delivery in South Africa. McDonald D and Pape J (eds.) Human Sciences Research Council Publishers, Cape Town, South Africa.

MSUNDUZI ACCOUNTS AND BILLING DEPARTMENT (2003) Telephonic communication with Accounts and Billing Department Official.

MSUNDUZI ADMINISTRATION (2003) Anonymous representative. Personal communication.

MSUNDUZI CITY ENGINEERS (2003) Anonymous representative. Personal communication.

MSUNDUZI CITY ENGINEERS (2005) Anonymous representative. Personal communication.

MSUNDUZI CREDIT CONTROL (2003) Anonymous representative Personal communication.

MSUNDUZI MUNICIPALITY (2001) Free Basic Water: proposed interim policy implementation. Report by the city engineer to the executive committee on 2 November 2001. Msunduzi City Engineers. 54-63.

MSUNDUZI NGO (2003) Anonymous civil society water stakeholder. Personal communication.

MSUNDUZI TARIFFS and CHARGES (2002/2003; 2003/2004; 2004/2005; 2005/2006) Accessed through Msunduzi Credit Control (2002, 2003, $2004 \&$ 2005).

MSUNDUZI WATER DEPARTMENT (2003) Anonymous representative. Telephonic communication.

PAUW J (2003) Metered to death: how a water experiment caused riots and a cholera epidemic. 2003. Published by the International Consortium for Investigative Journalism Center for Public Integrity, Washington. 5 February 2003. 4-5.

REPUBLIC OF SOUTH AFRICA (RSA) (1996) The Constitution. Government Printers, Pretoria.

REPUBLIC OF SOUTH AFRICA (RSA) (1997) Water Services Act. Government Printers, Pretoria, 108 of 1997.

REPUBLIC OF SOUTH AFRICA (RSA) (2000) Draft. In Local Government Property Rates Bill. Government Printers, Pretoria. 2 4-5.

RUDIN J (2003) Personal Communication. Via e-mail. South African Municipal Workers Union.

RUDIN J (2004) Personal Communication. Via email. South African Municipal Workers Union.

SHEPHERD M (2001) Free water-necessity is the mother of innovation: A practical approach by local authorities. IMIESA May 2001. 19 pp.

SMITH J (2003) Are South Africa's Water Service Delivery Policies and Strategies Equitable, Accessible, Affordable, Efficient, Effective and Sustainable for Msunduzi Low-income Households? Msocsci in Community Resources. School of Agricultural Sciences and Agriculture, University of Natal, Pietermaritzburg. Unpublished dissertation.

SUSSENS H and VERMEULEN A (2001) Providing free water in South Africa. Proc. $27^{\text {th }}$ WEDC Conf. People and Systems for Water, Sanitation and Health. Lusaka, Zambia 2001.

STATISTICS SOUTH AFRICA (2003) Census 2001. Digital Census Atlas [WWW document] URL http://www.statssa.gov.za/census2001/digiAtlas/index.html (accessed 1 August 2003).

VEOTTE L (2003) Personal communication. South African Municipal Workers Union. 